\title{
Effects of dietary sunflower seeds on rumen protozoa and growth of lambs
}

\author{
M. Ivan ${ }^{1,2 *}$, P. S. Mir ${ }^{1}$, Z. Mir ${ }^{1}$, T. Entz ${ }^{1}$, M. L. He ${ }^{1}$ and T. A. McAllister ${ }^{1}$ \\ ${ }^{1}$ Agriculture and Agri-Food Canada, PO Box 3000, Lethbridge, Alberta, Canada T1J 4 B1 \\ ${ }^{2}$ Agriculture and Agri-Food Canada, P.O. Box 40-2000 Road 108 East, Lennoxville, Quebec, Canada J1M $1 Z 3$ \\ (Received 15 October 2003 - Revised 1 March 2004 - Accepted 30 March 2004)
}

\begin{abstract}
Linoleic acid-rich sunflower-seed supplements (SSS) were used in two experiments (experiment 1, high-concentrate diets; experiment 2 , high-forage diets) to study effects on rumen protozoa and the growth of lambs. Both experiments consisted of four treatments, two with a low-protein diet $(120 \mathrm{~g} / \mathrm{kg})$ and two with a high-protein diet $(160 \mathrm{~g} / \mathrm{kg})$. For both diets, one treatment was without (control) and one with the SSS ( $140 \mathrm{~g} / \mathrm{kg}$ dietary DM). The lambs were fed ad libitum for 70 and $140 \mathrm{~d}$ in experiments 1 and 2, respectively. Thereafter, the digestibility of organic matter (OM), acid-detergent fibre and neutral-detergent fibre were determined for each diet with four lambs, and then all lambs were slaughtered and rumen fluid samples were collected and analysed. The results showed substantial decreases $(P<0.001)$ or total elimination of protozoa in the rumen fluid of the SSS-receiving lambs. In the first experiment the SSS also decreased $(P<0.05)$ feed intake, but an increase in average daily gain $(P<0.06)$ resulted in an improved $(P<0.05)$ feed:gain ratio. Also, the SSS increased $(P<0 \cdot 05)$ the digestibility of fibre. In the second experiment the SSS decreased $(P<0 \cdot 05)$ the OM digestibility, feed intake and growth of lambs. It was concluded that the use of sunflower-seed supplementation in high-concentrate diets of ruminants reduces rumen fauna, resulting in savings on dietary protein supplements and an increased digestion of feed.
\end{abstract}

Sunflower seeds: Rumen ciliate protozoa: Lamb growth

The microbial populations in the rumen consist mainly of bacteria, protozoa and fungi, and are involved in the digestion of feed in the rumen. Rumen bacteria provide the largest proportion of non- $\mathrm{NH}_{3}-\mathrm{N}$ entering the small intestine of the host ruminant (Robinson et al. 1996). Rumen ciliate protozoa are predators of rumen bacteria (Williams \& Coleman, 1992), but themselves contribute only a small proportion $\left(10-15 \%\right.$; Robinson et al. 1996) of non- $\mathrm{NH}_{3}$ $\mathrm{N}$ for utilisation by the host. Overall, rumen protozoa decrease the intestinal flow of amino acids (AA), mainly those of bacterial origin, by 23-30\% (Ivan et al. 2000a). This is a sizable amount that in most cases must be replaced as dietary protein to ensure that the protein requirement of the animal is met. Elimination of protozoa from the rumen (defaunation) results in an increased growth rate in young ruminants fed diets high in energy and low in rumen undegradable protein (Bird \& Leng, 1978, 1984; Bird et al. 1979). Defaunation is presently not practical due to the unavailability of a suitable defaunating agent (Hegarty, 1999). However, a considerable reduction in rumen fauna may also be beneficial as it increases milk yield and the protein:fat ratio in dairy cows (Moate, 1989). Sunflower-seed oil was found to be an effective dietary supplement that produces a massive reduction in the rumen protozoa population (Ivan et al. 2001). However, the extracted oil is relatively expensive for the purpose of dietary supplementation to ruminants. Therefore, we tested crushed sunflower seeds as a dietary antiprotozoal component (Ivan et al. 2003) and obtained results similar to those with a dietary sunflower-seed-oil supplement (Ivan et al. 2001). We hypothesised that a reduction in the rumen protozoa population should increase the rumen microbial synthesis of protein and, proportionally, reduce the requirement for dietary protein to sustain a similar growth in lambs. The objective of the present work was to test this hypothesis in two experiments with lambs, utilising sunflower-seed supplements (SSS) in concentrate- and forage-based diets. To measure the effects of the reduced protozoa populations on the dietary protein requirement, two, low $(120 \mathrm{~g} / \mathrm{kg})$ and high $(160 \mathrm{~g} / \mathrm{kg})$, dietary concentrations of protein were used in each experiment.

\section{Materials and methods}

\section{Experiment 1}

Fifty-six 14-week-old Canadian Arcott lambs were sheared, weighed and then divided according to weight and sex into four groups of fourteen animals each (seven males and seven females). The four dietary treatments were: (1) low-protein control (LPC); (2) low-protein diet with SSS

\footnotetext{
Abbreviations: AA, amino acids; ADG, average daily gain; ADF, acid-detergent fibre; HPC, high-protein control; HPS, high-protein diet with sunflowerseed supplement; LPC, low-protein control; LPS, low-protein diet with sunflower-seed supplement; NDF, neutral-detergent fibre; OM, organic matter; SSS, sunflower-seed supplement; VFA, volatile fatty acids.

* Corresponding author: Dr Michael Ivan, fax +1613254 9205, email ivanm@agr.gc.ca
} 
(LPS); (3) high-protein control (HPC); (4) high-protein diet with SSS (HPS). The experimental diets were based on rolled barley grain and are presented in Table 1. Crushed sunflower seeds (high-linoleic acid $(65 \cdot 10 \mathrm{~g} / \mathrm{kg}$ total oil) variety 6150) were supplemented at $140 \mathrm{~g} / \mathrm{kg}$ dietary DM, providing sunflower-seed oil in the amount of $60 \mathrm{~g} / \mathrm{kg}$ DM. Barley straw was used to balance the diets for approximate equal fibre content, while variable amounts of soyabean meal provided the desired protein concentration in the diets. Each diet was mixed as a single batch and pelleted. The lambs were offered feed ad libitum once daily (08.30 hours). Feed refusals were sampled, accumulated in a plastic bag for each lamb and stored in a freezer. A small quantity of each diet was taken at the time of feeding to form composite samples.

The lambs were housed in individual pens and had free access to feed and drinking water. Both the initial and final individual weighing was each performed on two consecutive days, after water and feed were withdrawn overnight. The average of the two consecutive weights, at both the beginning and the end of the experiment, was considered to be the start or finish body weight of each lamb. The lambs were also weighed individually every $14 \mathrm{~d}$ and records of feed intake were kept for each lamb throughout the $70 \mathrm{~d}$ experiment. After the last weighing, the lambs were sheared. Before the total shearing of each lamb a sample of wool ( 40 to $50 \mathrm{~g}$ ) was sheared from the hip area. The processing of wool samples and of the total fleece was as described previously (Ivan et al. 1992). One lamb (treatment LPS) was removed during the experiment due to health complications. The experimental protocol was approved by the local animal care committee and followed the guidelines of the Canadian Council on Animal Care (1993).
After completion of the shearing of all lambs, four male lambs of similar body weight from each treatment were placed in metabolism cages and fed $85 \%$ of the latest feed intake. They were fitted with harnesses and after $5 \mathrm{~d}$ of constant feed intake total faeces were collected for $5 \mathrm{~d}$. Faeces were collected into plastic bags and $10 \%$ of the daily output of each lamb was accumulated as a sample and frozen. The rest of the experimental lambs continued to receive the same diet ad libitum after the final weighing, and all lambs were harvested thereafter at a commercial slaughter facility.

Total rumen contents were removed, weighed, mixed and sampled. One half of each sample was strained through a single layer of cheesecloth for the enumeration of protozoa and $\mathrm{pH}$ was measured immediately. The second half was strained through two layers of cheesecloth for the determination of $\mathrm{NH}_{3}-\mathrm{N}$ and volatile fatty acids (VFA).

Ciliate protozoa were counted using a Neubauer Improved Bright-Line counting cell $(0.1 \mathrm{~mm}$ depth; Hausser Scientific, Horsham, PA, USA) in rumen fluid samples preserved with a methyl green-formalin-saline solution (Ogimoto \& Imai, 1981). Each sample was counted twice, and if the $\mathrm{CV}$ of the two counts was greater than $10 \%$ the counts were repeated.

A subsample $(10 \mathrm{ml})$ of rumen fluid was combined with $2 \mathrm{ml}$ of $25 \%(\mathrm{w} / \mathrm{v})$ meta-phosphoric acid before freezing for the analysis of VFA and $\mathrm{NH}_{3}-\mathrm{N}$. Later, the samples were thawed and centrifuged at $20000 \mathrm{~g}$ for $10 \mathrm{~min}$, then analysed for VFA using a Varian Star 3400 CX gas chromatograph (Varian Associates, Palo Alto, CA, USA) equipped with an 8200 autosampler and a fused silica column (DB-FFAP, $15 \mathrm{~m} \times 0.25 \mathrm{~mm}$ internal diameter; $\mathrm{J} \& \mathrm{~W}$ Scientific, Folsom, CA, USA). $\mathrm{NH}_{3}-\mathrm{N}$ was analysed

Table 1. Composition of the experimental diets

\begin{tabular}{|c|c|c|c|c|c|c|c|c|}
\hline & \multicolumn{4}{|c|}{ Experiment 1} & \multicolumn{4}{|c|}{ Experiment 2} \\
\hline & LPC & LPS & HPC & HPS & LPC & LPS & HPC & HPS \\
\hline \multicolumn{9}{|l|}{ Ingredient (g/kg DM) } \\
\hline Maize silage & & & & & $520 \cdot 0$ & $520 \cdot 0$ & $520 \cdot 0$ & $520 \cdot 0$ \\
\hline Maize grain (rolled) & & & & & 411.8 & 291.8 & 277.8 & $156 \cdot 8$ \\
\hline Barley grain (rolled) & $692 \cdot 8$ & 694.8 & 571.8 & 574.8 & & & & \\
\hline Barley straw & $202 \cdot 0$ & $112 \cdot 0$ & $202 \cdot 0$ & $110 \cdot 0$ & & & & \\
\hline Soyabean meal & 57.0 & $5 \cdot 0$ & $180 \cdot 0$ & $127 \cdot 0$ & $20 \cdot 0$ & & $154 \cdot 0$ & $135 \cdot 0$ \\
\hline Molasses (beet) & $20 \cdot 0$ & $20 \cdot 0$ & $20 \cdot 0$ & $20 \cdot 0$ & $20 \cdot 0$ & $20 \cdot 0$ & $20 \cdot 0$ & $20 \cdot 0$ \\
\hline Sunflower seeds (crushed) & & $140 \cdot 0$ & & $140 \cdot 0$ & & $140 \cdot 0$ & & $140 \cdot 0$ \\
\hline Dicalcium phosphate & $4 \cdot 0$ & 4.0 & 4.0 & 4.0 & $4 \cdot 0$ & 4.0 & 4.0 & 4.0 \\
\hline Limestone & $13 \cdot 0$ & $13 \cdot 0$ & $13 \cdot 0$ & $13 \cdot 0$ & $13 \cdot 0$ & $13 \cdot 0$ & $13 \cdot 0$ & $13 \cdot 0$ \\
\hline Trace mineral mix ${ }^{*}$ & $6 \cdot 0$ & $6 \cdot 0$ & $6 \cdot 0$ & $6 \cdot 0$ & $6 \cdot 0$ & $6 \cdot 0$ & $6 \cdot 0$ & $6 \cdot 0$ \\
\hline Vitamins $A, D$ and $E \dagger$ & 0.2 & 0.2 & 0.2 & 0.2 & 0.2 & 0.2 & 0.2 & 0.2 \\
\hline Zeolite & $5 \cdot 0$ & $5 \cdot 0$ & $5 \cdot 0$ & $5 \cdot \overline{0}$ & $5 \cdot 0$ & $5 \cdot 0$ & $5 \cdot 0$ & $5 \cdot 0$ \\
\hline \multicolumn{9}{|l|}{ Chemical analysis (g/kg DM) } \\
\hline Crude protein & 134 & 126 & 173 & 169 & 123 & 116 & 170 & 159 \\
\hline Acid-detergent fibre & 158 & 165 & 163 & 160 & 79 & 130 & 87 & 154 \\
\hline Neutral-detergent fibre & 345 & 398 & 350 & 350 & 200 & 313 & 223 & 336 \\
\hline \multicolumn{9}{|l|}{ Digestible energy } \\
\hline (calculated MJ/kg DM) & $13 \cdot 8$ & $15 \cdot 5$ & $13 \cdot 8$ & $15 \cdot 5$ & $13 \cdot 8$ & $15 \cdot 1$ & $13 \cdot 8$ & $15 \cdot 1$ \\
\hline
\end{tabular}

LPC, low-protein control; LPS, low-protein diet with sunflower-seed supplement; HPC, high-protein control; HPS, high-protein diet with sunflower-seed supplement.

${ }^{\star}$ Contained (g/kg): NaCl, 930.1; Dynamate, 50 (IMC-Agro Feed Ingredients Ltd, Oakville, Ontario, Canada; content (g/kg): S, 200; K, 180; Mg, 110; Fe, $1000 \mathrm{mg}$ ); $\mathrm{ZnSO}_{4} . \mathrm{H}_{2} \mathrm{O}, 9.2 ; \mathrm{MnSO}_{4} .4 \mathrm{H}_{2} \mathrm{O}, 8.3 ; \mathrm{CuSO}_{4} .5 \mathrm{H}_{2} \mathrm{O}, 1.3$; ethylenediamine dihydroiodide, $0.14 ; \mathrm{Na}_{2} \mathrm{SeO}_{3}, 0.03 ; \mathrm{CoSO}_{4} .6 \mathrm{H}_{2} \mathrm{O}, 0.05$ ). † Contained (per g vitamin mix): retinol, $3 \mathrm{mg}$; cholecalciferol, $25 \mu \mathrm{g}$; $\alpha$-tocopherol, $67 \mu \mathrm{g}$. 
in the same samples by the phenol-hypochlorite procedure (Broderick \& Kang, 1980).

Feed and faecal samples were oven-dried at $55^{\circ} \mathrm{C}$ to constant weight and then ground in a Wiley Mill to pass through a $1 \mathrm{~mm}$ screen and analysed for protein $(\mathrm{N} \times 6 \cdot 25)$ (Association of Official Analytical Chemists, 1984). Concentrations of acid-detergent fibre (ADF) and neutral-detergent fibre (NDF) were determined as described by van Soest et al. (1991), while organic matter (OM) was calculated as the DM loss during ashing at $550^{\circ} \mathrm{C}$. The digestibility of $\mathrm{OM}$, ADF or NDF was calculated as the percentage disappearance of the nutrient between the daily amount fed and the amount excreted in the faeces.

\section{Experiment 2}

The experimental procedure was essentially the same as that for experiment 1 with minor exceptions. There were twelve lambs (six males and six females) per treatment and these were fed high-forage diets based on maize silage and maize grain (Table 1). Variable amounts of soyabean meal provided the desired protein concentration in the diets. A premix of rolled maize grain, soyabean meal, molasses, crushed sunflower seeds (for LPS and HPS), dicalcium phosphate, limestone, minerals, vitamins and zeolite was prepared for each diet and pelleted. The pellets were mixed with maize silage daily in a Data Ranger (American Calan Inc., Northwood, NH, USA). A small quantity of each diet was taken at the time of mixing to form composite samples. Two lambs, one receiving the HPC treatment and one the HPS, were removed during the experiment due to health complications. The experiment lasted $140 \mathrm{~d}$.

\section{Statistical analysis}

For the protozoa counts in experiment 1, all of the animals in one treatment (LPS) had zero counts and large variations were observed for the other treatments. ANOVA could have been performed using log-transformed data with the treatment with all zeros omitted. However, it was decided to convert the protozoa counts to binary data (present, absent) for each animal and use 'Proc Genmod' (SAS Institute, Inc., 1999) to perform an analysis using a binomial generalised linear model with a logit link. Contrast statements were used to evaluate differences among estimates that were of interest when an effect was significant. 'Proc Mixed' (SAS Institute, Inc., 1999) was used to analyse the other dependent variables as a completely randomised design (Steel \& Torrie, 1980) with sunflower-seed treatment, dietary protein, and their interaction in the model as fixed effects. Main effect and interaction means were evaluated for significance using Fisher's protected least significant difference test and were considered significant if $P<0 \cdot 05$. The evaluation of interactions was important in the present study since it was expected that the SSS treatment would produce a response for the lowbut not for the high-protein treatments for some of the dependent variables.

\section{Results}

\section{Growth performance}

In experiment 1 , the numerically highest average daily gain (ADG; $319 \mathrm{~g}$ ) was achieved with the LPS and lowest $(276 \mathrm{~g})$ with the LPC diet (Table 2). The ADG with the HPC diet and the HPS was similar to that with the LPS. Although the main effect of the SSS was not significant, it was of interest to compare the least square means, which showed statistical differences between the LPC diet and the LPS at $P=0 \cdot 061$. This was associated with decreases in the average daily DM intake $(P<0.01)$ and the feed:gain ratio $(P<0 \cdot 001)$ due to the SSS. The ratio was highest (5.2) with the LPC diet and lowest (4.2) with the LPS, while due to the SSS the average daily DM intake decreased by $9 \%$. High dietary protein increased $(P<0.01)$ the total weight of clean fleece, but the other effects were not significant.

In experiment 2 , there were higher dietary concentrations of fibre (Table 1) in the SSS-containing diets (LPS, HPS) than in the control diets (LPC, HPC). The SSS decreased $(P<0.001)$ ADG from $240 \mathrm{~g}$ for the control to $191 \mathrm{~g}$ for the supplemented lambs (Table 2). This was associated with the decrease $(P<0.001)$ in average daily DM intake due to the SSS, without affecting $(P>0.05)$ the feed:gain ratio. The total weight of clean fleece was decreased $(P<0.05)$ by the SSS and increased $(P<0.01)$ by dietary protein.

\section{Digestibility}

In experiment 1 , the digestibility of $\mathrm{OM}$ was affected $(P<0 \cdot 05)$ by the SSS $\times$ protein interaction (Table 3$)$. The digestibility was not affected by the SSS with the low-protein diet (LPC $v$. LPS), but the OM digestibility increased $(P<0.05)$ from 72.1 to $75.8 \%$ when the SSS was included in the high-protein diet (HPC $v$. HPS). Both the SSS and high dietary protein significantly increased the digestibility of ADF and NDF.

In experiment 2 , the SSS decreased $(P<0.05)$ the percentage digestibility of $\mathrm{OM}$ from 75.8 to $72 \cdot 8$. The supplement had no significant effects on the digestibility of ADF and NDF.

\section{Protozoa and fermentation}

The number of protozoa, $\mathrm{pH}$, and $\mathrm{NH}_{3}-\mathrm{N}$ and VFA concentrations in the rumen fluid of lambs killed at the end of both experiments are summarised in Table 4. In experiment 1, the logit analysis for protozoa indicated a significant interaction $(P=0.01)$, and the contrast statements showed that the odds ratio for LPS was significantly lower than the other three odds ratios, which were similar. $\mathrm{NH}_{3}-\mathrm{N}$ concentrations were not affected by any factor or interaction, while $\mathrm{pH}(P<0.01)$ and VFA concentration $(P<0.05)$ were both affected by the SSS $\times$ protein interaction. The $\mathrm{pH}$ increased $(P<0.05)$ due to the SSS with the low-protein diet (LPC $v$. LPS), but decreased $(P<0.05)$ due to the supplement with the high-protein diet (HPC $v$. HPS). The effect of interaction on the concentration of VFA was reversed; the concentration decreased $(P<0.05)$ due 
Table 2. Growth and feed efficiency in lambs fed concentrate- (experiment 1) or forage- (experiment 2) based diets with a low (120 g/kg) or high $(160 \mathrm{~g} / \mathrm{kg}$ ) protein content and without (control) or with a sunflower-seed supplement (SSS)†

(Mean values with their standard errors)

\begin{tabular}{|c|c|c|c|c|c|c|c|c|c|c|c|c|}
\hline Treatment & \multicolumn{2}{|c|}{$\begin{array}{l}\text { Average start } \\
\text { weight }(\mathrm{kg})\end{array}$} & \multicolumn{2}{|c|}{$\begin{array}{c}\text { Average } \\
\text { finish weight } \\
(\mathrm{kg})\end{array}$} & \multicolumn{2}{|c|}{$\begin{array}{c}\text { Average } \\
\text { daily gain (g) }\end{array}$} & \multicolumn{2}{|c|}{$\begin{array}{l}\text { Average daily } \\
\text { DM intake }(\mathrm{g})\end{array}$} & \multicolumn{2}{|c|}{$\begin{array}{l}\text { Feed :gain } \\
\text { ratio }(g / g)\end{array}$} & \multicolumn{2}{|c|}{$\begin{array}{l}\text { Total weight } \\
\text { of fleece }(\mathrm{g})\end{array}$} \\
\hline \multicolumn{13}{|c|}{ Experiment 1 (high-concentrate diet; 70 d) } \\
\hline \multicolumn{13}{|c|}{ Main effects } \\
\hline \multicolumn{13}{|l|}{ SSS } \\
\hline Supplemented & & & & & 305 & 9 & $1335^{\mathrm{b}}$ & 30 & $4 \cdot 4^{\mathrm{b}}$ & $0 \cdot 1$ & 518 & 15 \\
\hline \multicolumn{13}{|l|}{ Protein } \\
\hline Low & & & & & 293 & 11 & 1389 & 34 & $4 \cdot 7$ & $0 \cdot 2$ & $476^{a}$ & 16 \\
\hline High & & & & & 296 & 8 & 1412 & 31 & $4 \cdot 8$ & 0.1 & $549^{\mathrm{b}}$ & 20 \\
\hline \multicolumn{13}{|l|}{ Interaction } \\
\hline Low-protein control & $25 \cdot 4$ & $1 \cdot 0$ & $44 \cdot 7$ & $1 \cdot 6$ & 276 & 16 & 1423 & 52 & $5 \cdot 2$ & 0.3 & 457 & 17 \\
\hline Low-protein diet + SSS & $25 \cdot 6$ & $1 \cdot 1$ & $47 \cdot 9$ & 1.5 & $319^{*}$ & 14 & 1352 & 43 & $4 \cdot 2$ & 0.1 & 497 & 27 \\
\hline High-protein control & $25 \cdot 4$ & 0.9 & $45 \cdot 9$ & 0.9 & 293 & 12 & 1504 & 30 & $5 \cdot 1$ & 0.2 & 561 & 38 \\
\hline SSS & & & & & & & 0.0 & & $0 \cdot($ & & & \\
\hline Protein & & & & & & & 0.5 & & $0 \cdot 5$ & & & \\
\hline Interaction & & & & & & & 0.1 & & & & & \\
\hline \multicolumn{13}{|c|}{ Experiment 2 (high-forage diet; $140 \mathrm{~d}$ ) } \\
\hline \multicolumn{13}{|c|}{ Main effects } \\
\hline \multicolumn{13}{|l|}{ SSS } \\
\hline Control & & & & & $240^{a}$ & 10 & $1104^{a}$ & 43 & $4 \cdot 6$ & 0.1 & $673^{a}$ & 27 \\
\hline Supplemented & & & & & $191^{\mathrm{b}}$ & 7 & $892^{b}$ & 32 & $4 \cdot 7$ & 0.1 & $587^{\mathrm{b}}$ & 33 \\
\hline \multicolumn{13}{|l|}{ Protein } \\
\hline Low & & & & & 210 & 8 & 993 & 40 & $4 \cdot 7$ & 0.1 & $571^{a}$ & 29 \\
\hline High & & & & & 222 & 11 & 1003 & 48 & 4.5 & 0.1 & $694^{b}$ & 29 \\
\hline \multicolumn{13}{|l|}{ Interaction } \\
\hline Low-protein control & $18 \cdot 5$ & 1.5 & $50 \cdot 1$ & $3 \cdot 1$ & 226 & 14 & 1078 & 64 & $4 \cdot 8$ & 0.1 & 611 & 39 \\
\hline Low-protein diet + SSS & $18 \cdot 4$ & 1.4 & 45.5 & $1 \cdot 7$ & 194 & 6 & 908 & 37 & $4 \cdot 7$ & 0.2 & 531 & 41 \\
\hline High-protein control & $18 \cdot 8$ & 1.5 & 54.5 & 2.9 & 255 & 13 & 1132 & 57 & 4.4 & 0.1 & 741 & 27 \\
\hline High-protein diet + SSS & $17 \cdot 9$ & 1.6 & 44.4 & $2 \cdot 8$ & 189 & 13 & 874 & 54 & 4.6 & 0.2 & 648 & 48 \\
\hline \multicolumn{13}{|l|}{ Effects $(P)$} \\
\hline Interaction & & & & & & & 0.4 & & 0.5 & & & \\
\hline
\end{tabular}

a,b Mean values in a column, for SSS or protein, with unlike superscript letters were significantly different $(P<0.05)$.

* Mean value was statistically different from the low-protein control $(P=0.06)$.

†For details of diets and procedures, see Table 1 and p. 303.

to the SSS with the low-protein diet (LPC $v$. LPS), but tended $(P>0.05)$ to increase with the high-protein diet (HPC $v$. HPS).

In experiment 2 , the number of protozoa $/ \mathrm{ml}$ rumen fluid decreased $(P<0 \cdot 001)$ from 730000 to 60000 due to the SSS, but was not affected by the dietary protein $(P>0 \cdot 05)$. The $\mathrm{pH}$ was increased $(P<0 \cdot 05)$ by the supplement and decreased $(P<0 \cdot 01)$ by high dietary protein. Both $\mathrm{NH}_{3}-\mathrm{N} \quad(P<0.001)$ and VFA $(P<0.05)$ concentrations were increased by high dietary protein, while the other effects were not significant.

\section{Discussion}

The presence of ciliate protozoa in the rumen of sheep decreases the flow of AA from the stomach to the intestinal tract for absorption and utilisation by up to $30 \%$ (Ivan et al. 1991, 2000a,b). Most of such a decrease must be compensated for in the form of an increased dietary protein concentration to ensure that the $\mathrm{N}$ requirement is met to achieve the optimal productivity of the animal. In the present study, the difference in protein concentration between the low- and high-protein diets was, therefore, set at approximately $30 \%(120$ v. $160 \mathrm{~g} / \mathrm{kg})$. Actual differences after chemical analysis of the experimental diets were $29 \%$ and over. Since concentrated energy sources such as fats and oils reduce protozoa (Clemens et al. 1974; Machmüller et al. 2000) and inhibit cellulolytic rumen bacteria (Henderson, 1973), no attempt was made to make the diets in the two experiments isoenergetic.

Use of the SSS in the concentrate diets with equal fibre content in experiment 1 increased ADG in the lambs fed the LPS compared with the LPC diet. It is interesting to note that the ADG in the lambs receiving the LPS was even numerically higher than in those receiving the highprotein diets (HPC and HPS). It is obvious that the difference is not a response to the slightly higher energy content in the LPS as compared with the LPC diet. This is because there was an almost identical difference in energy content between the two high-protein diets (HPC v. HPS), while 
Table 3. Percentage digestibility of organic matter (OM), acid-detergent fibre (ADF) and neutral-detergent fibre (NDF) in lambs fed concentrate- (experiment 1) or forage- (experiment 2) based diets with a low (120 g/kg) or high $(160 \mathrm{~g} / \mathrm{kg}$ ) protein content and without (control) or with a sunflower-seed supplement (SSS)* (Mean values with their standard errors)

\begin{tabular}{|c|c|c|c|c|c|c|}
\hline & \multicolumn{2}{|c|}{ OM } & \multicolumn{2}{|c|}{ ADF } & \multicolumn{2}{|c|}{ NDF } \\
\hline & Mean & SE & Mean & SE & Mean & SE \\
\hline \multicolumn{7}{|c|}{ Experiment 1 (high-concentrate diet; $70 \mathrm{~d}$ ) } \\
\hline \multirow{2}{*}{\multicolumn{7}{|c|}{$\begin{array}{l}\text { Main effects } \\
\text { SSS }\end{array}$}} \\
\hline & & & & & & \\
\hline Control & $71 \cdot 2$ & 0.57 & $22 \cdot 9^{\mathrm{a}}$ & 1.23 & $36 \cdot 8^{\mathrm{a}}$ & 1.04 \\
\hline Supplemented & $73 \cdot 1$ & 1.17 & $30 \cdot 7^{\mathrm{b}}$ & $2 \cdot 00$ & $46 \cdot 3^{\mathrm{b}}$ & 1.69 \\
\hline \multicolumn{7}{|l|}{ Protein } \\
\hline Low & $70 \cdot 3$ & 0.30 & $24 \cdot 0^{\mathrm{a}}$ & $1 \cdot 22$ & $39.2^{\mathrm{a}}$ & 1.40 \\
\hline High & 73.9 & 0.93 & $29 \cdot 5^{\mathrm{b}}$ & $2 \cdot 51$ & $43.9^{\mathrm{b}}$ & 2.63 \\
\hline \multicolumn{7}{|l|}{ Interaction } \\
\hline Low-protein control & $70 \cdot 2^{a}$ & 0.22 & 21.3 & 1.04 & $35 \cdot 8$ & 0.91 \\
\hline Low-protein diet + SSS & $70 \cdot 3^{a}$ & 0.61 & $26 \cdot 8$ & 0.91 & $42 \cdot 7$ & 0.74 \\
\hline High-protein control & $72 \cdot 1^{\mathrm{a}}$ & 0.95 & 24.4 & $2 \cdot 10$ & $37 \cdot 8$ & 1.89 \\
\hline High-protein diet + SSS & $75 \cdot 8^{\mathrm{b}}$ & 1.03 & 34.5 & $2 \cdot 80$ & $50 \cdot 0$ & 1.96 \\
\hline \multicolumn{7}{|l|}{ Effects $(P)$} \\
\hline SSS & \multicolumn{2}{|c|}{0.029} & \multirow{2}{*}{\multicolumn{2}{|c|}{$\begin{array}{l}0.001 \\
0.014\end{array}$}} & \multicolumn{2}{|c|}{0.001} \\
\hline Protein & \multicolumn{2}{|c|}{0.001} & & & & \\
\hline \multirow{2}{*}{\multicolumn{7}{|c|}{ Experiment 2 (high-forage diet; 140 d) }} \\
\hline & & & & & & \\
\hline \multicolumn{7}{|c|}{ Main effects } \\
\hline \multicolumn{7}{|l|}{ SSS } \\
\hline Control & $75 \cdot 8^{\mathrm{a}}$ & 1.17 & $40 \cdot 0$ & 3.00 & $46 \cdot 3$ & $2 \cdot 21$ \\
\hline Supplemented & $72 \cdot 8^{\mathrm{b}}$ & 0.68 & 38.0 & 1.41 & $41 \cdot 1$ & 1.56 \\
\hline \multicolumn{7}{|l|}{ Protein } \\
\hline Low & 73.0 & 1.13 & $35 \cdot 8$ & 2.46 & 41.6 & $2 \cdot 22$ \\
\hline High & 75.5 & 0.85 & $42 \cdot 2$ & 1.55 & $45 \cdot 8$ & 1.74 \\
\hline \multicolumn{7}{|l|}{ Interaction } \\
\hline Low-protein control & 73.9 & 1.97 & $35 \cdot 3$ & 5.01 & 43.5 & 4.02 \\
\hline Low-protein diet + SSS & $72 \cdot 2$ & 1.24 & $36 \cdot 4$ & 1.72 & 39.8 & 2.09 \\
\hline High-protein control & $77 \cdot 6$ & 0.36 & $44 \cdot 7$ & 1.58 & $49 \cdot 0$ & 1.26 \\
\hline High-protein diet + SSS & 73.4 & 0.57 & 39.7 & $2 \cdot 13$ & $42 \cdot 5$ & $2 \cdot 38$ \\
\hline \multicolumn{7}{|l|}{ Effects $(P)$} \\
\hline SSS & \multirow{2}{*}{\multicolumn{2}{|c|}{$\begin{array}{l}0.031 \\
0.060\end{array}$}} & \multirow{2}{*}{\multicolumn{2}{|c|}{$\begin{array}{l}0.520 \\
0.054\end{array}$}} & \multicolumn{2}{|c|}{0.077} \\
\hline Protein & & & & & \multirow{2}{*}{\multicolumn{2}{|c|}{$\begin{array}{l}0.145 \\
0.621\end{array}$}} \\
\hline Interaction & \multicolumn{2}{|c|}{0.325} & \multicolumn{2}{|c|}{0.328} & & \\
\hline
\end{tabular}

a,b Mean values in a column, for SSS, protein or interaction, with unlike superscript letters were significantly different $(P<0.05)$

${ }^{\star}$ For details of diets and procedures, see Table 1 and p. 303.

the ADG for the two high-protein diets were almost the same. This is a clear evidence of the beneficial effect of the SSS when used in a low-protein diet. There was a high variation in ADG among individual lambs. Undoubtedly, the level of the significance of the differences between the LPC diet and the LPS would increase with a higher number of lambs per group. Also, as expected, there was no benefit of the addition of the SSS to the high-protein diet, which decreased the level of probability of the main effect of the SSS on ADG. The superiority of the SSS is further demonstrated by the improved feed:gain ratio, as a result of the lower DM intake required to produce greater growth performance. Since there were no protozoa present in the rumen of the lambs fed the LPS, it would be expected that there was a higher yield of bacterial protein in the rumen of these lambs. Such expectation is due to the removal of the protozoal predatory activity (Demeyer \& van Nevel, 1979), resulting in lower rumen concentrations of $\mathrm{NH}_{3}-\mathrm{N}$ and a higher intestinal flow of AA (Veira et al. 1983, 1984; Kayouli et al. 1986; Ivan et al. 1991). Consequently, because wool growth is positively affected by the increased intestinal supply of protein, especially sulfur AA (Reis \& Schinckel, 1961; Bird \& Leng, 1984; Ivan et al. 1992), there should be more wool growth in the lambs fed the LPS than in the lambs fed the LPC diet. However, the results show no effects of the SSS on wool growth in experiment 1.

The wool yield increased with the increased dietary protein in both of the present experiments. Therefore, it appears that in experiment 1 the lack of the expected increase in the clean fleece yield in the lambs fed the LPS to the level of the high-protein diets (HPC or HPS) was due to an insufficient intestinal supply of AA. Because wool growth is sensitive to the intestinal protein (AA) supply (Reis \& Schinckel, 1961) and ADG is sensitive to the protein (AA):energy ratio (Leng, 1993), it is reasonable to suggest that the addition of the SSS to the low-protein diet increased the intestinal supply of AA and energy to the level required for the increased ADG. But, the intestinal supply of AA in the LPS-fed lambs was probably not high enough to support more wool growth, up to that obtained with the HPC diet or the HPS. This is further 
Table 4. Protozoa numbers and fermentation parameters in rumen fluid taken after slaughter at the end of feeding trials with lambs fed concentrate- (experiment 1) or forage- (experiment 2) based diets with a low (120 g/kg) or high (160 g/kg) protein content and without (control) or with a sunflower-seed supplement (SSS)†

(Mean values with their standard errors)

\begin{tabular}{|c|c|c|c|c|c|c|c|c|}
\hline & \multicolumn{2}{|c|}{$\begin{array}{c}\text { Protozoa* } \\
\text { (number } \times 10^{6} / \mathrm{ml} \text { ) }\end{array}$} & \multicolumn{2}{|c|}{$\mathrm{pH}$} & \multicolumn{2}{|c|}{$\begin{array}{c}\mathrm{NH}_{3}-\mathrm{N} \\
(\mathrm{mg} / 100 \mathrm{ml})\end{array}$} & \multicolumn{2}{|c|}{$\begin{array}{l}\text { Total VFA } \\
(\mathrm{mmol} / \mathrm{l})\end{array}$} \\
\hline & Mean & SE & Mean & SE & Mean & SE & Mean & SE \\
\hline \multicolumn{9}{|c|}{ Experiment 1 (high-concentrate diet; 70 d) } \\
\hline \multicolumn{9}{|c|}{ Main effects } \\
\hline Control & $5 \cdot 46$ & 1.679 & $6 \cdot 1$ & $0 \cdot 16$ & $8 \cdot 4$ & 1.50 & 121 & $7 \cdot 8$ \\
\hline Supplemented & $1 \cdot 18$ & 0.644 & $6 \cdot 2$ & 0.17 & $4 \cdot 7$ & 1.75 & 102 & 8.9 \\
\hline \multicolumn{9}{|l|}{ Protein } \\
\hline Low & 1.00 & 0.546 & $6 \cdot 1$ & $0 \cdot 12$ & $5 \cdot 2$ & $1 \cdot 26$ & 117 & $8 \cdot 4$ \\
\hline High & $5 \cdot 64$ & 1.677 & $6 \cdot 3$ & $0 \cdot 21$ & $8 \cdot 0$ & 1.99 & 106 & $8 \cdot 9$ \\
\hline \multicolumn{9}{|l|}{ Interaction } \\
\hline Low-protein control & 1.99 & 0.98 & $5 \cdot 8^{a}$ & 0.05 & $7 \cdot 4$ & 1.84 & $140^{\mathrm{a}}$ & $4 \cdot 8$ \\
\hline Low-protein diet + SSS & 0.00 & 0.00 & $6 \cdot 4^{\mathrm{bc}}$ & 0.18 & 2.9 & 1.33 & $94^{\mathrm{b}}$ & $10 \cdot 1$ \\
\hline High-protein control & 8.92 & 2.69 & $6 \cdot 8^{b}$ & 0.06 & $9 \cdot 5$ & 2.46 & $101^{\mathrm{b}}$ & $11 \cdot 0$ \\
\hline High-protein diet + SSS & $2 \cdot 36$ & $1 \cdot 15$ & $6 \cdot 1^{\mathrm{ac}}$ & 0.30 & $6 \cdot 6$ & $3 \cdot 22$ & $110^{\mathrm{ab}}$ & $14 \cdot 7$ \\
\hline \multicolumn{9}{|l|}{ Effects $(P)$} \\
\hline SSS & \multicolumn{2}{|c|}{0.001} & \multicolumn{2}{|c|}{0.832} & \multicolumn{2}{|c|}{0.124} & \multicolumn{2}{|c|}{0.094} \\
\hline Protein & \multicolumn{2}{|c|}{0.512} & \multicolumn{2}{|c|}{0.099} & \multicolumn{2}{|c|}{0.234} & \multicolumn{2}{|c|}{0.319} \\
\hline Interaction & \multicolumn{2}{|c|}{0.016} & \multicolumn{2}{|c|}{0.006} & \multicolumn{2}{|c|}{0.730} & \multicolumn{2}{|c|}{0.017} \\
\hline \multicolumn{9}{|c|}{ Experiment 2 (high-forage diet; 140 d) } \\
\hline \multicolumn{9}{|c|}{ Main effects } \\
\hline \multicolumn{9}{|l|}{ SSS } \\
\hline Control & $0.73^{\mathrm{a}}$ & 0.189 & $6 \cdot 4^{\mathrm{a}}$ & 0.09 & $4 \cdot 2$ & 0.73 & 94 & $7 \cdot 4$ \\
\hline Supplemented & $0.06^{\mathrm{b}}$ & 0.034 & $6 \cdot 7^{\mathrm{b}}$ & 0.10 & $4 \cdot 0$ & 0.99 & 79 & $5 \cdot 8$ \\
\hline \multicolumn{9}{|l|}{ Protein } \\
\hline Low & 0.30 & 0.128 & $6 \cdot 7^{\mathrm{a}}$ & 0.08 & $1 \cdot 7^{\mathrm{a}}$ & 0.30 & $75^{\mathrm{a}}$ & $4 \cdot 3$ \\
\hline High & 0.49 & 0.176 & $6 \cdot 3^{b}$ & 0.11 & $6 \cdot 8^{\mathrm{b}}$ & 0.95 & $99^{\mathrm{b}}$ & $8 \cdot 1$ \\
\hline \multicolumn{9}{|l|}{ Interaction } \\
\hline Low-protein control & 0.58 & 0.234 & $6 \cdot 6$ & 0.10 & $2 \cdot 3$ & 0.51 & 81 & $5 \cdot 5$ \\
\hline Low-protein diet + SSS & 0.02 & 0.017 & $6 \cdot 9$ & 0.11 & $1 \cdot 1$ & 0.23 & 69 & 6.4 \\
\hline High-protein control & 0.89 & 0.307 & $6 \cdot 2$ & $0 \cdot 15$ & $6 \cdot 4$ & $1 \cdot 12$ & 108 & $13 \cdot 2$ \\
\hline High-protein diet + SSS & 0.10 & 0.068 & 6.5 & 0.15 & $7 \cdot 2$ & 1.58 & 90 & $9 \cdot 3$ \\
\hline Effects $(P)$ & & & & & & & & \\
\hline SSS & & & & & & & & \\
\hline Protein & & & & & & & & \\
\hline Interaction & & & & & & & & \\
\hline
\end{tabular}

${ }^{a, b, c}$ Mean values in a column, for SSS, protein or interaction, with unlike superscript letters were significantly different $(P<0.05)$.

* The protozoa probabilities in experiment 1 come from the logit analysis of binary data (observed, not observed), but the counted means are shown in the Table for consistency.

†For details of diets and procedures, see Table 1 and p. 303.

supported by the higher digestibility of ADF and NDF due to the SSS in experiment 1 . Increases in these digestibilities probably resulted in a higher supply of energy and in an improved available AA:energy ratio for the growth of the LPS-fed lambs.

Contrary to experiment 1 , the SSS produced a $19 \%$ decrease in $\mathrm{ADG}$ in experiment 2. Since the feed:gain ratio was not affected, the decrease was most certainly due to the proportionally lower feed intake as a result of the higher fibre content and the lower digestibility of the SSS-containing diets compared with the control diets. The digestibility of OM was decreased by the SSS added to the high-forage diet, without significant changes in the digestibility of ADF and NDF (experiment 2 ). In contrast, the addition of the SSS to the concentrate diet (experiment 1) increased the digestibility of both ADF and NDF, while that of OM was not affected. This indicates a clear advantage of the SSS when used in high-concentrate diets, but not when used as part of the concentrate in high-forage diets.
It should be noted that in experiment 1 the $\mathrm{pH}$ increased and VFA concentration decreased, while protozoa disappeared when the SSS was added to the low-protein diet (LPC $v$. LPS). It has been suggested that protozoa exert a stabilising effect on $\mathrm{pH}$, because their partial or total removal results in a lower and more variable rumen $\mathrm{pH}$ (Veira et al. 1983). Rumen fauna contains cellulolytic protozoa (Coleman, 1985) and some bacterial enzymes and growth are inhibited by a decline in $\mathrm{pH}$ (Blackburn \& Hobsen, 1960; Russell et al. 1979), contributing to lower digestibility. Therefore, because protozoa disappeared from the rumen, a decline in the digestibility of feed due to the disappearance in the lambs fed the LPS and HPS in experiment 1 would be expected, but it did not appear. In contrast, the digestibility of fibre was increased in these lambs, probably due to improved rumen conditions provided by the SSS for the growth of cellulolytic bacteria.

The present results confirmed our previous observation of the antiprotozoal effects of the SSS (Ivan et al. 2003) 
and its ability to reduce or completely eliminate rumen fauna. Depending on the diet used, such effects may increase the synthesis of microbial protein in the rumen and the efficiency of the dietary protein utilisation. This would lower substantially the protein requirement for the maximum growth of young ruminants. It would also lower the excretion and manure content of N. Since protozoa supply hydrogen to methanogens they contribute to the rumen production of methane by up to $25 \%$ (U.S. Environmental Protection Agency, 1993). Therefore, in addition to the beneficial effects on production the SSS may also reduce the excretion of methane by ruminant livestock through the inhibition of methanogenesis (Whitelaw et al. 1984).

Use of the SSS in high-concentrate diets contributes to the dietary protein and effective fibre, and according to the present study, it increases the feed conversion efficiency and digestibility of fibre. Beneficial effects of a reduced fauna on milk production and quality has been reported previously (Moate, 1989), but the reduction of fauna was achieved by a chemical method (drenching with Alkanate 3SL3). Such a method is not practical for use in animal production. Also, most of the existing experimental defaunating techniques negatively affect rumen bacteria, especially cellulolytic species. There is at present no safe practical technique commercially available for the reduction or elimination of rumen fauna (Hegarty, 1999). Therefore, to the knowledge of the authors, the use of sunflower-seed oil (Ivan et al. 2001) or crushed sunflower seeds (Ivan et al. 2003; experiment 1) as an antiprotozoal dietary component in concentrate diets is the first safe and practical means for the beneficial reduction of protozoa populations in the rumen. The present study shows that the SSS increases the digestion of high-concentrate diets, probably partly through increased $\mathrm{pH}$, which benefits cellulolytic bacteria (Blackburn \& Hobsen, 1960; Russell et al. 1979) and partly through a reduced protozoa population that affects the numbers and species composition of the rumen bacteria population (Williams \& Coleman, 1992).

It can be concluded from the results of the present study that, depending on the type of diet used, the antiprotozoal effects of sunflower-seed supplementation might be beneficial to ruminant production. The present study demonstrates for the first time that a reduced fauna may contribute to a higher efficiency of dietary protein utilisation and consequent savings on dietary protein supplements. Additional benefits of sunflower-seed supplementation might come from a reduced environmental impact of ruminant production.

\section{Acknowledgements}

The authors wish to thank C. Barkley for dedicated technical assistance, and the staff at the sheep barn for animal care and help with rumen sampling. The authors are grateful for the research fund contribution by the Dairy Farmers of Canada and the Matching Investment Initiative of Agriculture and Agri-Food Canada. The high-linoleic acid variety of sunflower seeds used in the present two experiments was kindly donated by the Pioneer High-Bred International
Ltd. The present study's Lethbridge Research Centre contribution number was 387 (03053).

\section{References}

Association of Official Analytical Chemists (1984) Official Methods of Analysis, 14th ed. Arlington, VA: AOAC.

Bird SH, Hill MK \& Leng RA (1979) The effect of defaunation of the rumen on the growth of lambs on low-protein high-energy diets. Br J Nutr 42, 81-87.

Bird SH \& Leng RA (1978) The effects of defaunation of the rumen on the growth of cattle on low-protein high-energy diets. Br J Nutr 40, 163-167.

Bird SH \& Leng RA (1984) Further studies on the effects of the presence or absence of protozoa in the rumen on liveweight gain and wool growth in sheep. Br J Nutr 52, 607-611.

Blackburn TH \& Hobsen PN (1960) Proteolysis in the sheep rumen by whole and fractionated rumen contents. J Gen Microbiol 22, 272-281.

Broderick GA \& Kang JH (1980) Automated simultaneous determination of ammonia and total amino acids in ruminal fluid and in vitro media. J Dairy Sci 63, 64-75.

Canadian Council on Animal Care (1993) Guide to the Care and Use of Experimental Animals, vol. 1 [ED Olfert, BM Cross and AA McWilliams, editors]. Ottawa, Ontario, Canada: CCAC.

Clemens E, Woods W \& Arthaud V (1974) The effect of feeding unsaturated fats as influenced by gelatinized corn and by the presence or absence of rumen protozoa. Part I. Serum lipid composition. J Anim Sci 38, 634-639.

Coleman GS (1985) The cellulase content of 15 species of entodiniomorphid protozoa, mixed bacteria and plant debris isolated from the ovine rumen. J Agric Sci 104, 349-360.

Demeyer DI \& van Nevel CJ (1979) Effect of defaunation on the metabolism of rumen micro-organisms. Br J Nutr 42, 515-524.

Hegarty RS (1999) Reducing rumen methane emission through elimination of rumen protozoa. Aust Agric Res 50, 1321-1327.

Henderson C (1973) The effects of fatty acids on pure cultures of rumen bacteria. J Agric Sci (Cambridge) 81, 107-112.

Ivan M, Dayrell MS, Mahadevan S \& Hidiroglou M (1992) Effects of bentonite on wool growth and nitrogen metabolism in fauna-free and faunated sheep. J Anim Sci 70, 3194-3202.

Ivan M, Entz T, Mir PS, Mir Z \& McAllister TA (2003) Effects of sunflower seed supplementation and different dietary protein concentrations on the ciliate protozoa population dynamics in the rumen of sheep. Can J Anim Sci 83, 809-817.

Ivan M, Hidiroglou M \& Petit HV (1991) Duodenal flow of nitrogen following protozoal inoculation of fauna-free sheep fed a diet supplemented with casein or soybean meal. Can J Anim Sci 71, 793-801.

Ivan M, Mir PS, Koenig KM, Rode LM, Neill L, Entz T \& Mir Z (2001) Effects of dietary sunflower oil on rumen protozoa population and tissue concentration of conjugated linoleic acid in sheep. Small Rum Res 41, 215-227.

Ivan M, Neill L \& Entz T (2000a) Ruminal fermentation and duodenal flow following progressive inoculations of fauna-free wethers with major individual species of ciliate protozoa or total fauna. J Anim Sci 78, 750-759.

Ivan M, Neill L, Forster R, Alimon R, Rode LM \& Entz T (2000b) Effects of Isotricha, Dasytricha, Entodinium, and total fauna on ruminal fermentation and duodenal flow in wethers fed different diets. J Dairy Sci 83, 776-787.

Kayouli C, van Nevel CJ, Dendooven R \& Demeyer DI (1986) Effect of defaunation and refaunation of the rumen on rumen fermentation and nitrogen flow in the duodenum of sheep. Arch Tierernähr 36, 827-838.

Leng RA (1993) Quantitative ruminant nutrition - a green science. Aust J Agric Res 44, 363-380. 
Machmüller A, Ossowski DA \& Kreuzer M (2000) Comparative evaluation of the effects of coconut oil, oilseeds and crystalline fat on methane release, digestion and energy balance in lambs. Anim Feed Sci Technol 85, 41-60.

Moate PJ (1989) Defaunation increases milk yield of dairy cows. In Recent Advances in Animal Nutrition in Australia 1989, p. 18A [DJ Farrell, editor]. Armidale, NSW: University of New England Printery.

Ogimoto K \& Imai S (1981) Atlas of Rumen Microbiology. Tokyo: Japan Scientific Societies.

Reis PJ \& Schinckel PG (1961) Nitrogen utilization and wool production in sheep. Aust J Agric Res 12, 335-352.

Robinson PH, Fadel JG \& Ivan M (1996) Critical evaluation of diaminopimelic acid and ribonucleic acid as markers to estimate rumen pools and duodenal flows of bacterial and protozoal nitrogen. Can J Anim Sci 76, 587-597.

Russell JB, Sharp WM \& Baldwin RL (1979) The effect of pH on maximum bacterial growth rate and its possible role as determinant of bacterial competition in the rumen. J Anim Sci 48, 251-255.

SAS Institute, Inc. (1999) SAS/STAT User's Guide, version 8. Cary, NC: SAS Institute, Inc.

Steel RGD \& Torrie JH (1980) Principles and Procedures of
Statistics: a Biometrical Approach, 2nd ed. New York: McGraw-Hill.

U.S. Environmental Protection Agency (1993) Options for Reducing Methane Emissions Internationally: vol. II - International Opportunities for Reducing Methane Emissions. Report to Congress, EPA 430-R-006 B. Washington, DC: U.S. Environmental Protection Agency.

van Soest PJ, Robertson JB \& Lewis BA (1991) Methods for dietary fiber, neutral detergent fiber, and nonstarch polysaccharides in relation to animal nutrition. J Dairy Sci $\mathbf{7 4 ,}$ $3583-3597$.

Veira DM, Ivan M \& Jui PY (1983) Rumen ciliate protozoa: effects on digestion in the stomach of sheep. J Dairy Sci $\mathbf{6 6}$, $1015-1022$.

Veira DM, Ivan M \& Jui PY (1984) The effect of ciliate protozoa on the flow of amino acids from the stomach of sheep. Can $J$ Anim Sci 64, Suppl., 22.

Whitelaw FG, Eadie JM, Bruce LA \& Shand WJ (1984) Methane formation in faunated and ciliate-free cattle and its relationship with rumen volatile fatty acid proportions. Br J Nutr 52, 261-275.

Williams AG \& Coleman GS (1992) The Rumen Protozoa. New York: Springer-Verlag. 